\title{
Sanitary Hazards and Microbial Quality of Open Dug Wells in the Maldives Islands
}

\author{
Shivasorupy Barthiban ${ }^{1}$, Barry J. Lloyd ${ }^{1}$, Mathias Maier ${ }^{2}$ \\ ${ }^{1}$ Centre for Environmental Health Engineering, University of Surrey, Guildford, UK \\ ${ }^{2}$ Stadwerke Karlshruhe, Karlsruhe, Germany \\ Email: enp2ss@surrey.ac.uk
}

Received March 14, 2012; revised April 18, 2012; accepted May 27, 2012

\begin{abstract}
Concern for saline and microbial quality post-December 2004 tsunami, led to a field based surveillance study to systematically investigate the sanitary hazards which cause faecal contamination of groundwater. In seven islands, two duplicate sample sets, in two surveys, revealed that only $6.4 \%$ of the 173 well water samples (combining both surveys) satisfied the WHO Drinking Water Quality Guideline for $44^{\circ} \mathrm{C}$ thermo-tolerant (Faecal) Coliform (FC) indicator value (zero cfu/100ml sample). Based on a combined risk analysis of Sanitary Hazard Score (SHS) and FC counts, more than $57.7 \%$ of the study wells were classified as at very high (FC: 100 to $>1000 \mathrm{cfu} / 100 \mathrm{ml}$; and SHS: $\geq 9$ ) microbial health risk. During this study, fundamental changes were made to the published generic sanitary inspection method (WHO, 1997) for identifying sanitary hazards, for its application in the extremely vulnerable hydro-geological setting of the Maldives. However, the most important hazard controlling the intensity of faecal contamination in the Maldives is the safe separation distance between a latrine seepage point and the well. It was demonstrated that, due to the prevailing hydro-geological conditions and the well and sanitation system densities, safe separation distance cannot be achieved. Consequently, septic tank effluent quality must be greatly improved.
\end{abstract}

Keywords: Surveillance of Wells; Faecal Coliform Counts; Sanitary Survey; Sanitary Hazard Score

\section{Introduction}

Groundwater exploitation using shallow dug wells is a common practice in Asia including the Maldives islands. Following a number of major water-borne disease outbreaks linked to polluted groundwater in the 1970s and 1980 s, rainwater storage became the primary source of drinking water in the Maldives [1]. The GoM-UNICEF (2000) estimated that $75 \%$ of the Maldives population relies on rainwater tanks for drinking water, and the figure would be $87 \%$ if Male, the island capital, is not considered (cited in [1]). Male Island receives much of its drinking water from desalination plants. Falkland [2] estimated that the average total water use in the Maldives varies between 50 and $100 \mathrm{l} / \mathrm{p} / \mathrm{c} / \mathrm{d}$ with the actual amount depending largely on the presence or absence of a flush toilet. Out of the $50-100 \mathrm{l} / \mathrm{p} / \mathrm{c} / \mathrm{d}$ of daily water use, only $5-10 \mathrm{l} / \mathrm{p} / \mathrm{c} / \mathrm{d}$ is consumed from rainwater [1]. This indicates that groundwater is still widely exploited for other domestic purposes in the Maldives.

Most of the rainwater tanks used in the remote Maldives islands are used up and go dry during dry seasons [3]. During this period people consume water from mosque wells, which is believed (by the inhabitants) to have good quality water. In addition, prolonged drought and less predictable rainy seasons, caused by global climatic change, led to a necessity to store the excess rainwater during the wet season for the water scarce period. The very small land area of the Maldives means that the groundwater aquifer is the only potential and feasible reservoir available for excess rainwater storage in addition to rainwater tanks. Therefore it is very important to protect the groundwater quality, and the dug wells, through which it is exploited.

Together with salinization issues, the sanitation practices followed in the Maldives islands are critical to contamination of groundwater. It is a common practice in the Maldives to construct a sanitation unit (either squatting plate or flushing toilet) next to the domestic shallow dug well, within the bathing room. The latrine pits are located within the same small house plot, leaving the separation distance between the pit and the well less than $10 \mathrm{~m}$, in most cases. This is owing to high population density in the inhabited area of each island. Continuous usage of on-site sanitation systems over a period of time can also contribute to increase chloride concentration levels in the freshwater lens, additional to the faecal contamination which occurs [4].

If timely remedial and protective actions are not taken, 
the Maldives islands will lose their precious groundwater resource which is already limited in extent. Also, due to the changing pattern of the climate, rainwater tanks may not be a comprehensive solution for the water needs of the inhabitants of the remote islands. Hence, as part of a doctoral research project, a pilot scale well surveillance study was carried out in selected islands to assess the current risks and future sustainability of the well water. This paper presents the results of two surveillance study periods in four islands and preliminary findings in a further three islands, with respect to groundwater faecal contamination levels and hazard identification of open dug wells.

\section{Aims and Objectives}

The aims of the core project were to identify and critically assess the sanitary hazards associated with well water, and evaluate the applicability of published water surveillance methods as described in this paper. The overall objective of the project was to formulate a remedial action strategy. The medium to long term objectives are to develop a groundwater conservation and protection strategy.

\section{Literature Review}

On-site sanitation systems can be an important cause of the microbial contamination of well water. Nevertheless, unsanitary conditions of the well and the well head area can also permit the rapid ingress of pathogens into well water [5-9]. The microbial contamination of well water can be analyzed using the source-pathway-receptor relationship where, source is the origin of the pathogens; pathway is the route through which the pathogens reach the well water; and, the receptor is the well water. Successful remedial action to improve the microbial well water quality begins with the identification of the source and pathway of the contaminants to the receptor.

Lloyd and Helmer [8] developed a surveillance methodology to assess the drinking water quality and associated hazards in water supplies in rural areas. The surveillance methodology included a check-list of hazards (Text Box 1) to assess the sanitary conditions of water supplies as part of a sanitary survey form, together with the assessment of the microbial water quality using $44^{\circ} \mathrm{C}$ thermo-tolerant FC counts.

Lloyd and Helmer [8] (in Peru, Indonesia [Java] and Zambia), and Lloyd and Boonyakarnkul [10] (in Thailand), showed that the combined risk analysis of the sanitary survey results and the FC counts was an efficient means of identifying and prioritizing water supply hazards for remedial action. The effectiveness of the remedial action was assessed with a follow up survey. This surveillance methodology, which was later published in
Text Box 1. A checklist of hazards.

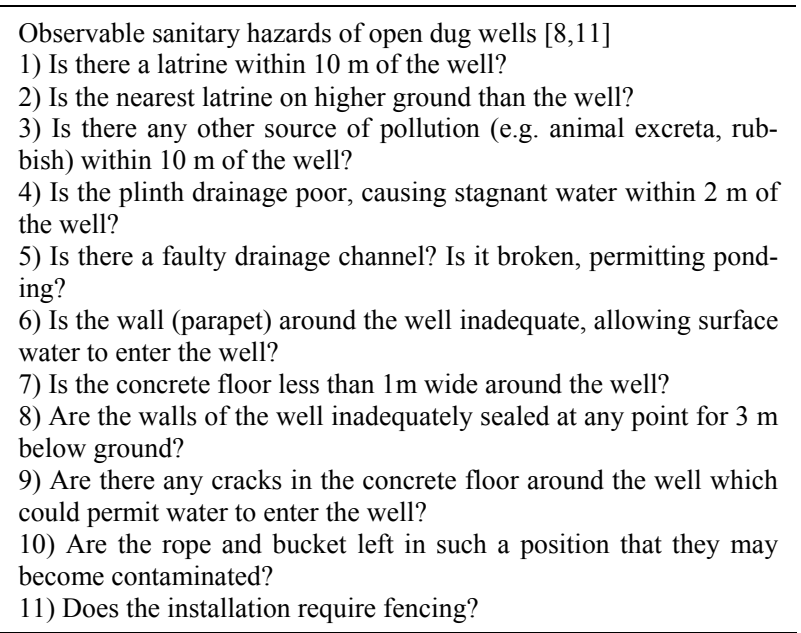

WHO Guidelines for Drinking Water Quality [11], is relatively simple, yet robust, in identifying the potential sources of microbial health risks associated with drinking water supply. This methodology is useful in the context of developing countries which often lack advanced technology and financial resources.

\section{Study Area}

\section{The Maldives Islands}

The Republic of Maldives is a group of 1200 islets spread approximately over a distance of $868 \mathrm{~km}$ in the Indian Ocean. Of those, only 200 Maldivian islands are officially classified as inhabited. The Maldives islands spread over the equator between latitudes $7^{\circ} 06^{\prime} 30^{\prime \prime} \mathrm{N}$ and $0^{\circ} 41^{\prime} 48^{\prime \prime} \mathrm{S}$ and Longitudes $72^{\circ} 32^{\prime} 30^{\prime \prime} \mathrm{E}$ and $73^{\circ} 45^{\prime} 54^{\prime \prime} \mathrm{E}$.

Seven study islands; Vilufushi, Thimarafushi, Veymandoo, Burunee, Fenfushi, Thoddoo and Daravandhoo, were chosen for the study by the director of the Maldives Water and Sanitation Authority (MWSA). The study islands were selected based on the history of water quality issues. Tables 1 and $\mathbf{2}$ summarize some information about the study islands. According to the best information available to the lead author there was no previous systematic well surveillance study carried out in the Maldives islands to assess the health risks associated with open dug wells.

\section{Project Outline and Methods}

This study involved a field based surveillance programmme carried out in the selected islands of the Maldives to systematically collect data about sanitary hazards of abstraction wells and the quality, including thermo-tolerant (faecal) coliform (FC) counts, of groundwater.

Sanitary survey and well water sampling for FC counts were carried out during day time. The surveillance work 
Table 1. Some fundamental characteristics of the Maldives study islands.

\begin{tabular}{|c|c|c|c|c|c|c|c|c|}
\hline \multicolumn{2}{|r|}{ Study Area } & Vilufushi & Thimarafushi & Veymandoo & Burunee & Fenfushi & Thoddoo & Daravandhoo \\
\hline \multicolumn{2}{|r|}{ Area (ha) } & 61 & 14.5 & 40.8 & 30.5 & 24.2 & 173.8 & 56.1 \\
\hline \multirow{3}{*}{ Population } & Resident Population & 0 & 2408 & 1018 & 566 & 795 & 1475 & 966 \\
\hline & $\begin{array}{l}\text { Internally Displaced Population } \\
\text { (IDP) by the } 2004 \text { Tsunami }\end{array}$ & 0 & $-{ }^{* *}$ & - & 2018 & - & - & - \\
\hline & Reconstruction Workers & 425 & 0 & 0 & 0 & - & - & - \\
\hline \multicolumn{2}{|r|}{ Population Density (/ha) } & 7 & 166 & 25 & 85 & 33 & 9 & 18 \\
\hline \multicolumn{2}{|c|}{ Approximate Well/Latrine Density ${ }^{*} /$ ha) } & 2 & 28 & 5 & 15 & 6 & 2 & 3 \\
\hline
\end{tabular}

*Every house in the remote Maldives islands has an individual household well and an on-site sanitation system and average number of people in a dwelling is assumed to be $6 ;{ }^{* *}$ Exact number not known (could be around 100 ).

Table 2. Summary of borehole permeability test results from three islands in the Maldives.

\begin{tabular}{ccccc}
\hline Borehole Code \& Island & Depth of Test Zone (m) & $\begin{array}{c}\text { Number of Falling Head } \\
\text { Tests in Zone }\end{array}$ & $\begin{array}{c}\text { Average Permeability for } \\
\text { Test Zone (m/day) }\end{array}$ & Source of Data \\
\hline H2, Hithadhoo & $3.0-4.0$ & 3 & 4 & Falkland, December 2000 \\
HOA2 Hoarafushi & $3.0-4.0$ & 4 & 2.1 & Falkland, August 2001 \\
HAN1 Hanimaadhoo & $3.0-4.0$ & 3 & 30.9 & \\
\hline
\end{tabular}

Sources: $[2,12]$

in the Maldives was carried out from November 2007 to January 2009. Random sampling of the well water was carried out in each study island. The sampling locations in each study island were selected such that the observations present a representative picture of the current groundwater quality condition in each island studied.

The published sanitary survey form to assess the sanitary conditions of open dug wells $[8,11]$ was used as a tool to assess the sanitary conditions of open dug wells in the Maldives islands. When a hazard, likely to cause faecal contamination of the well, is observed, the relevant survey question was marked as "Yes". Then, at the end of the survey all the questions with "Yes" answers are added to get the Sanitary Hazard Score (SHS) for graphical display against FC counts and grades for each well. The FC grades are explained in Table 3.

To present surveillance data for collections of wells, Lloyd \& Helmer [8] proposed that, as a preliminary assessment, equal weighting be given to every observed sanitary hazard present in the operational courtyard and well head area of each well. This was done with a view to adding together all recorded hazards to provide a SHS which could be plotted against FC grades for each well in an administrative area. The principal reason for this combined hazard/FC assessment plot was to identify the worst wells, with most hazards and highest FC counts, in most urgent need of rehabilitation. The graphs could also be used to investigate a simple hypothesis, that the greater the number of hazards, the greater the probability of increased faecal contamination. There proved to be only weak positive correlations in well studies in Java and Thailand $[8,10]$, indicating that some hazards were
Table 3. E. coli/faecal coliform classification scheme for water supplies.

\begin{tabular}{ccc}
\hline Grade & $\begin{array}{c}\text { Faecal coliform } \\
\text { counts (cfu/100ml) }\end{array}$ & Risk \\
\hline A & 0 & No risk \\
B & $1-10$ & Low risk \\
C & $11-100$ & Intermediate to high risk \\
D & $101-1000$ & Gross pollution; high risk \\
E & $>1000$ & Gross pollution; very high risk \\
\hline
\end{tabular}

Sources: [8].

more important than others. The combined analysis, of hazards and FC counts, was subsequently analyzed by a simple multivariate method by Lloyd and Boonyakarnkul [10], to identify the relative importance (weighting) of different sanitary hazards in contributing to the intensity of faecal contamination. They produced a sanitary hazard index to place in rank order all recorded hazards, and assessed the impact of remedial measures (removing specific hazards) on tube wells in Thailand.

In this project the FC counts of the dug well water was assessed using the DelAgua field test kit and the International Standards Organization membrane filtration technique [13]. At each study location duplicate well water samples were processed to assess the reproducibility of the method by the lead author, whilst a MWSA field officer collected the duplicate water samples.

Considering the statistical confidence level for FC colony counts, the homogeneity levels of the FC grades A-E (Table 4) obtained for each set of duplicate samples demonstrated the satisfactory reproducibility (levels 1 
Table 4. Comparison of the homogeneity of the observed faecal coliform grades between duplicate well water samples 1 and 2 , by study islands in the Maldives.

\begin{tabular}{|c|c|c|c|c|c|c|c|c|c|c|c|c|c|c|c|c|c|}
\hline \multicolumn{2}{|c|}{ Homogeneity levels } & \multicolumn{5}{|c|}{ Level $1(\%)$} & \multicolumn{4}{|c|}{ Level $2(\%)$} & \multicolumn{3}{|c|}{ Level 3 (\%) } & \multicolumn{2}{|c|}{$\begin{array}{c}\text { Level } 4 \\
(\%)\end{array}$} & \multirow{2}{*}{$\begin{array}{c}\begin{array}{c}\text { Level } 5 \\
(\%)\end{array} \\
\mathrm{AE}\end{array}$} & \multirow{2}{*}{$\begin{array}{c}\text { No. of } \\
\text { samples }\end{array}$} \\
\hline Study area & Period & AA & BB & $\mathrm{CC}$ & DD & $\mathrm{EE}$ & $\mathrm{AB}$ & $\mathrm{BC}$ & $\mathrm{CD}$ & $\mathrm{DE}$ & $\mathrm{AC}$ & $\mathrm{BD}$ & $\mathrm{CE}$ & $\mathrm{AD}$ & $\mathrm{BE}$ & & \\
\hline \multirow{2}{*}{ Vilufushi } & Jan-08 & 0 & 0 & 0 & 2 & 1 & 0 & 1 & 1 & 0 & 0 & 0 & 0 & 0 & 0 & 0 & \multirow{2}{*}{5} \\
\hline & Total & \multicolumn{5}{|c|}{$3(60.0)$} & \multicolumn{4}{|c|}{$2(40.0)$} & & $0(0.0)$ & & \multicolumn{2}{|c|}{$0(0.0)$} & $0(0.0)$ & \\
\hline \multirow{2}{*}{ Thimarafushi } & Jan-08 & 0 & 3 & 1 & 6 & 3 & 1 & 1 & 4 & 2 & 0 & 0 & 1 & 0 & 0 & 0 & \multirow{2}{*}{22} \\
\hline & Total & \multicolumn{5}{|c|}{$13(59.1)$} & \multicolumn{4}{|c|}{$8(36.4)$} & & $1(4.5)$ & & \multicolumn{2}{|c|}{$0(0.0)$} & $0(0.0)$ & \\
\hline \multirow{2}{*}{ Veymandoo } & Jan- 08 & 0 & 2 & 4 & 5 & 5 & 1 & 0 & 3 & 1 & 0 & 0 & 0 & 0 & 0 & 0 & \multirow{2}{*}{21} \\
\hline & Total & \multicolumn{5}{|c|}{$16(76.2)$} & \multicolumn{4}{|c|}{$5(23.8)$} & & $0(0.0)$ & & \multicolumn{2}{|c|}{$0(0.0)$} & 0 & \\
\hline \multirow{2}{*}{ Burunee } & Jan-08 & 0 & 2 & 2 & 8 & 2 & 1 & 1 & 0 & 0 & 0 & 0 & 0 & 0 & 0 & 0 & \multirow{2}{*}{16} \\
\hline & Total & \multicolumn{5}{|c|}{$14(87.5)$} & \multicolumn{4}{|c|}{$2(12.5)$} & & $0(0.0)$ & & \multicolumn{2}{|c|}{$0(0.0)$} & $0(0.0)$ & \\
\hline$\Gamma_{0} \mathrm{f}^{\circ}$ & Feb-08 & 0 & 6 & 1 & 0 & 4 & 4 & 1 & 0 & 0 & 0 & 0 & 0 & 0 & 0 & 0 & 16 \\
\hline ( & Total & & & (68. & & & & & & & & $0(0.0)$ & & & & $0(0.0)$ & 10 \\
\hline Thimorof & May-08 & 1 & 0 & 5 & 11 & 6 & 0 & 0 & 0 & 0 & 0 & 0 & 0 & 0 & 0 & 0 & \\
\hline & Total & & & $(100$ & & & & & & & & $0(0.0)$ & & & & $0(0.0)$ & \\
\hline Veyn & May-08 & 1 & 1 & 2 & 6 & 4 & 4 & 1 & 2 & 0 & 0 & 0 & 0 & 0 & 0 & 0 & 0 \\
\hline 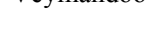 & Total & & & (66. & & & & & .3) & & & $0(0.0)$ & & & & $0(0.0)$ & \\
\hline Burunee & May-08 & 0 & 1 & 6 & 3 & 4 & 0 & 1 & 1 & 0 & 0 & 0 & 0 & 0 & 0 & 0 & 16 \\
\hline & Total & & & (87. & & & & & $.5)$ & & & $0(0.0)$ & & & & $0(0.0)$ & \\
\hline Thod & May-08 & 6 & 0 & 1 & 2 & 3 & 0 & 0 & 1 & 1 & 0 & 0 & 2 & 0 & 0 & 0 & \\
\hline & Total & & & (75. & & & & & & & & $2(12.5$ & & & & $0(0.0)$ & \\
\hline Dorayondbo & Oct-08 & 2 & 3 & 2 & 0 & 0 & 1 & 0 & 0 & 0 & 0 & 0 & 0 & 0 & 0 & 0 & 8 \\
\hline & Total & & & $(87$. & & & & & $.5)$ & & & $0(0.0)$ & & & & $0(0.0)$ & \\
\hline Darava & Dec-08 & 1 & 1 & 0 & 4 & 0 & 0 & 0 & 1 & 0 & 0 & 0 & 0 & 0 & 0 & 0 & 7 \\
\hline & Total & & & (85. & & & & & .3) & & & $0(0.0)$ & & & & $0(0.0)$ & \\
\hline Overall & Overall & 11 & 19 & 24 & 47 & 32 & 12 & 6 & 13 & 4 & 0 & 0 & 3 & 0 & 0 & 0 & 171 \\
\hline & Total & & & $3(77$ & & & & 35 & $0.5)$ & & & $3(1.8)$ & & & & $0(0.0)$ & \\
\hline
\end{tabular}

and 2) of results by the sampling team alongside control blank samples. Hence the mean of the duplicate data sets (samples 1 and 2) was used in the combined analysis.

In addition to the first batch of well survey (with samples $1 \& 2$ ), a second batch of well water quality and sanitary surveys of the same wells were undertaken in four numbers of islands. These two surveys were separated by two (in Daravandhoo island) to four (in Thimarafushi, Veymandoo and Burunee islands) months duration. The time between the two surveys was dependent on the MWSA logistics to arrange the field work.

The second batch of surveys in the Maldives study islands were carried out to:

- Assess the reproducibility of the sanitary hazard methodology and data;

- Attempt to determine whether any changes had occurred in quality characteristics.

\section{Results and Discussion}

\subsection{Faecal Coliform (FC) Grades}

The percentage occurrence of the observed FC grades, arranged by study islands and surveys, is presented in Table 5. Overall results showed that only $6.4 \%$ of the samples satisfied the WHO Drinking Water Quality Guideline value (zero counts $/ 100 \mathrm{ml}$ of sample). FC grade "D" (101 - $1000 \mathrm{cfu} / 100 \mathrm{ml})$ was the most frequently $(35.8 \%)$ observed well water faecal contamination level in the Maldives. Overall $78 \%$ of the wells showed FC grades equal to, or greater than, C-grade (11 - 100 $\mathrm{cfu} / 100 \mathrm{ml})$. That is, a high proportion of the studied wells in the Maldives is grossly polluted and is at high risk.

Unlike duplicate sample sets, the observed FC grades of the first and the second batch of surveys of the same 
Table 5. Frequency (percentage) of occurrence of thermo-tolerant (faecal) coliform grades, arranged by sampling periods.

\begin{tabular}{|c|c|c|c|c|c|c|c|}
\hline \multirow{2}{*}{ Study islands } & \multirow{2}{*}{ Period } & \multicolumn{5}{|c|}{ Frequency (percentage) occurrence of FC Grade } & \multirow{2}{*}{$\begin{array}{l}\text { No. of } \\
\text { samples }\end{array}$} \\
\hline & & $\mathrm{A}(0)$ & $\mathrm{B}(1-10)$ & $\mathrm{C}(11-100)$ & $\mathrm{D}(101-1000)$ & $\mathrm{E}(>1000)$ & \\
\hline Vilufushi & Jan-08 & $0(0.0)$ & $0(0.0)$ & $1(20.0)$ & $3(60.0)$ & $1(20.0)$ & 5 \\
\hline Thimarafushi & Jan-08 & $0(0.0)$ & $1(4.5)$ & $5(22.7)$ & $12(54.5)$ & $4(18.2)$ & 22 \\
\hline Veymandoo & Jan-08 & $0(0.0)$ & $3(14.3)$ & $5(23.8)$ & $8(38.1)$ & $5(23.8)$ & 21 \\
\hline Burunee & Jan-08 & $0(0.0)$ & $2(12.5)$ & $4(25.0)$ & $8(50.0)$ & $2(12.5)$ & 16 \\
\hline \multicolumn{2}{|c|}{ Overall Jan-08 } & \multicolumn{5}{|c|}{$\geq \mathrm{C}$ grade $=58(90.6)$} & 64 \\
\hline Fenfushi & Feb-08 & $0(0.0)$ & $10(62.5)$ & $2(12.5)$ & $0(0.0)$ & $4(25.0)$ & 16 \\
\hline \multicolumn{2}{|c|}{ Overall Feb-08 } & $0(0.0)$ & $10(62.5)$ & $\begin{array}{c}2(12.5) \\
\geq C \text { grade }=6(\end{array}$ & $0(0.0)$ & $4(25.0)$ & 16 \\
\hline Thoddoo & May-08 & $6(37.5)$ & $0(0.0)$ & $2(12.5)$ & $2(12.5)$ & $6(37.5)$ & 16 \\
\hline Thimarafushi & May-08 & $1(4.3)$ & $0(0.0)$ & $5(21.7)$ & $13(56.5)$ & $4(17.4)$ & 23 \\
\hline Veymandoo & May-08 & $1(4.8)$ & $5(23.8)$ & $3(14.3)$ & $8(38.1)$ & $4(19.0)$ & 21 \\
\hline Burunee & May-08 & $0(0.0)$ & $1(6.3)$ & $8(50.0)$ & $3(18.8)$ & $4(25.0)$ & 16 \\
\hline \multicolumn{2}{|c|}{ Overall May-08 } & $8(10.5)$ & \multicolumn{3}{|c|}{$\geq \mathrm{C}$ grade $=62(81.6)$} & $18(23,7)$ & 76 \\
\hline Daravandhoo & Oct-08 & $2(25.0)$ & $4(50.0)$ & $2(25.0)$ & $0(0.0)$ & $0(0.0)$ & 8 \\
\hline \multicolumn{2}{|c|}{ Overall Oct-08 } & $2(25.0)$ & $4(50.0)$ & $\begin{array}{c}2(25.0) \\
\geq C \text { grade }=2(\end{array}$ & $0(0.0)$ & $0(0.0)$ & 8 \\
\hline Daravandhoo & Dec-08 & $1(11.1)$ & $1(11.1)$ & $2(22.2)$ & $5(55.6)$ & $0(0.0)$ & 9 \\
\hline \multicolumn{2}{|c|}{ Overall Dec-08 } & $1(11.1)$ & $1(11.1)$ & $\begin{array}{c}2(22.2) \\
\geq \mathrm{C} \text { grade }=7(\end{array}$ & $5(55.6)$ & $0(0.0)$ & 9 \\
\hline \multicolumn{2}{|c|}{ Overall } & \multicolumn{4}{|c|}{$\geq \mathrm{C}$ grade $=135(78.0)$} & $34(19.7)$ & 173 \\
\hline
\end{tabular}

wells (separated by 2 - 4 months) did not show good homogeneity levels (Table 6) which could be a result of many factors, such as rainfall events and time of sampling during a single day (Table 7).

Rainfall can increase bacterial contamination with the onset of rainfall, because the matrix force between the bacteria (including pathogens) and the soil particles are broken. With continuing rainfall the quality improves, because of dilution of contaminants with rainfall recharge. Flushing out of the contaminants from the groundwater system may also occur at the coastline. However, dramatic daytime variation in $\mathrm{FC}$ counts in a single well (Ve03), across the full range of $\mathrm{FC}$ grades A-E, is recorded in Table 7. The peak FC count was very strongly (and almost instantaneously) linked to very recent latrine contamination of well water by the user in the same household. This provides the best confirmation of the source-pathway-receptor principle.

\subsection{Sanitary Surveys}

This section discusses the relevance of the sanitary hazards listed in the published sanitary survey form for open dug wells, in the context of the observations specific to the Maldives.

Q1: Is there a latrine within $10 \mathrm{~m}$ of the well?

This question checks whether the open dug well is located at less than a safe separation distance from an onsite sanitation system. Here, $10 \mathrm{~m}$ safe separation distance was used as a general guideline value. What could be the safe separation distance in the context of the Maldives study islands where the aquifers are classed as extremely vulnerable and there is virtually no soil layer?

The British Geological Survey guidelines for Assessing the Risk to Groundwater from On-Site Sanitation (ARGOSS) defines the groundwater abstraction system as being at significant risk when it is located at a distance less than 25 day groundwater travel time from an on-site sanitation system [4]. This corresponds to a much greater distance than $10 \mathrm{~m}$ in the Maldivian aquifer context.

The summary of borehole test results carried out by Falkland $[2,12]$ is presented in Table 2. According to Table 2 the average permeability at a depth of 3.0 to 4.0 $\mathrm{m}$ varied from $2.1 \mathrm{~m} /$ day to $30.9 \mathrm{~m} /$ day in different study 
Table 6. Comparison of the observed faecal coliform grades between the preliminary and follow up surveys arranged by study islands in the Maldives.

\begin{tabular}{|c|c|c|c|c|c|c|c|c|c|c|c|c|c|c|c|c|}
\hline \multirow{2}{*}{$\begin{array}{l}\text { Homogeneity } \\
\text { levels }\end{array}$} & \multicolumn{5}{|c|}{ Level $1(\%)$} & \multicolumn{4}{|c|}{ Level $2(\%)$} & \multicolumn{3}{|c|}{ Level $3(\%)$} & \multicolumn{2}{|c|}{ Level $4(\%)$} & \multirow{2}{*}{$\begin{array}{c}\text { Level } 5(\%) \\
\mathrm{AE}\end{array}$} & \multirow{2}{*}{$\begin{array}{c}\text { Total } \\
\text { no. of } \\
\text { samples }\end{array}$} \\
\hline & AA & $\mathrm{BB}$ & $\mathrm{CC}$ & DD & $\mathrm{EE}$ & $\mathrm{AB}$ & $\mathrm{BC}$ & $\mathrm{CD}$ & $\mathrm{DE}$ & $\mathrm{AC}$ & $\mathrm{BD}$ & $\mathrm{CE}$ & $\mathrm{AD}$ & $\mathrm{BE}$ & & \\
\hline \multirow{2}{*}{$\begin{array}{l}\text { Thimarafushi } \\
\text { island }\end{array}$} & 0 & 0 & 2 & 8 & 2 & 0 & 0 & 3 & 3 & 1 & 1 & 2 & 0 & 0 & 0 & \multirow{2}{*}{22} \\
\hline & & & $(54$ & & & & 6( & .3) & & & $(18.2$ & & & & $0(0.0)$ & \\
\hline \multirow{2}{*}{ Veymandoo island } & 0 & 2 & 2 & 2 & 2 & 0 & 0 & 4 & 4 & 0 & 3 & 0 & 1 & 1 & 0 & \multirow{2}{*}{21} \\
\hline & \multicolumn{5}{|c|}{$8(38.1)$} & \multicolumn{4}{|c|}{$8(38.1)$} & \multicolumn{3}{|c|}{$3(14.3)$} & \multicolumn{2}{|c|}{$2(9.52)$} & $0(0.0)$ & \\
\hline \multirow{2}{*}{ Burunee island } & 0 & 0 & 2 & 0 & 0 & 0 & 0 & 6 & 3 & 0 & 2 & 2 & 0 & 1 & 0 & \multirow{2}{*}{16} \\
\hline & \multicolumn{5}{|c|}{$2(12.5)$} & \multicolumn{4}{|c|}{$9(56.3)$} & \multicolumn{3}{|c|}{$4(25.0)$} & \multicolumn{2}{|c|}{$1(6.25)$} & $0(0.0)$ & \\
\hline \multirow{2}{*}{$\begin{array}{l}\text { Daravandhoo } \\
\text { island }\end{array}$} & 1 & 1 & 0 & 0 & 0 & 0 & 1 & 3 & 0 & 0 & 1 & 0 & 0 & 0 & 0 & \multirow{2}{*}{7} \\
\hline & \multicolumn{5}{|c|}{$2(28.6)$} & \multicolumn{4}{|c|}{$4(57.1)$} & \multicolumn{3}{|c|}{$1(14.3)$} & \multicolumn{2}{|c|}{$0(0.0)$} & $0(0.0)$ & \\
\hline
\end{tabular}

Table 7. Daytime FC counts profile showing considerable variation with sampling time observed at Ve03 in the Veymandoo island.

\begin{tabular}{ccc}
\hline Date & Time (hrs) & $\begin{array}{c}\text { Average FC counts } \\
(\mathrm{cfu} / 100 \mathrm{ml})\end{array}$ \\
\hline $7: 40: 00$ & 4 \\
$9: 05: 00$ & 12 \\
$11: 00: 00$ & 0 \\
$13: 05: 00^{*}$ & 1049 \\
$15: 15: 00$ & 41 \\
$17: 03: 00$ & 8 \\
\hline
\end{tabular}

*The land lady had just finished using the bathroom (had a bath for sure, and had also used the toilet).

islands in the Maldives.

Assuming a minimum permeability value of $2.1 \mathrm{~m} /$ day at the specific depth among those summarized in Table 2, the distance of 25 day groundwater travel time will be at least $52.5 \mathrm{~m}$. Therefore, if the separation distance between a dug well and an on-site sanitation system in the Maldives islands is less than $52.5 \mathrm{~m}$, then the dug well is at high risk of microbiological contamination. Therefore Q1 of the survey form needs to be modified according to the hydro-geological setting e.g., Q1: Is there a latrine within $52.5 \mathrm{~m}$ of the well? In the context of the Maldives islands.

It is common practice in the Maldives islands to build the latrine facility next to the well, or within the wash room, which is also shared by the domestic well. However, the latrine pit (septic tank) is located further away from the latrine, but within the compound. Therefore question 1 in the sanitary survey form should be concerned with the latrine pit (septic tank), rather than the location of the latrine in the context of the Maldives, because, unless the latrine plate and waste pipe are damaged, it is the leachate from the latrine pit which causes the great majority of the faecal contamination of groundwater. A latrine pit located within the safe separation distance of a well will be treated as a hazard only when the latrine has the potential to contaminate the well water. Dry, on-site, sanitation systems do not pose a threat to the microbial groundwater quality (unless it is directly contaminated), because there will not be leachate coming out of the pit. However, as in the case of the Maldives islands, wet on-site sanitation systems are likely to be the major source of faecal contamination of groundwater and well water.

In the context of the Maldives islands, question one should be modified as, Q1: Is there a latrine within 52.5 $m$ of the well?

Now, the maximum possible separation distance between two latrines located within an area of 1 ha can be $39.9 \mathrm{~m}$ (2 times the area of a circle with a radius of 39.9 $m$ is equal to $1 \mathrm{ha}$ ). All individual houses in the Maldives study islands own a well and an on-site sanitation system. Hence the feasible separation distance between a well and an on-site sanitation system will be less than $39.9 \mathrm{~m}$; this is less than the separation distance of significant risk ( $52.5 \mathrm{~m}$ in the context of the Maldives islands) as defined in BGS ARGOSS guidelines [4] The overall maximum and the minimum observed separation distances between a well and a latrine observed in the Maldives study islands were $36.1 \mathrm{~m}$ and $1.0 \mathrm{~m}$ respectively, with an average value of $8.1 \mathrm{~m}$. Also, the latrine density in the Maldives study islands were above 2 no./ha. Therefore all the latrine effluents in this Maldives study were located within the safe separation distance of the well!

The maximum feasible separation distance between two wells, in the Maldives islands, is $39.9 \mathrm{~m}$. Therefore, depending on the rate of well water abstraction, the natural groundwater flow direction can be altered in the vicinity of the well for some time until the cone of depression caused by the groundwater abstraction fully recovered to the level of groundwater table. Considering the high density of on-site sanitation systems and open dug wells, every individual well is surrounded by more than one on-site sanitation system. This situation pro- 
vides more opportunities for the leachates from any onsite sanitation system to reach one or more wells rapidly. Therefore the answer to this altered question (Q1) will always be "Yes" in the case of the Maldives islands studied, and thus becomes both the commonest and the most important hazard. Considering these facts (and based on the BGS ARGOSS guidelines [4]), it is concluded that maintaining a safe separation distance between an open dug well and an on-site sanitation system is not possible in most of the Maldives islands.

Q2: Is the nearest latrine on higher ground than the well?

The second question in the published survey form is intended to reinforce Q1 where groundwater flow direction is likely to increase the risk of faecal contamination from latrines. However, since the topography of the Maldives is almost flat there is virtually no down-gradient flow, Question 2 can therefore be excluded. Furthermore, it is not possible to deduce the potential for the leachate from the latrine to reach the well water without tracer study information about the groundwater flow direction. However, this information was not available for the Maldives.

Q2: Is the nearest latrine on higher ground than the well? Of the published survey form is redundant and will not be considered further.

Q3: Is there any other source of pollution (e.g. animal excreta, rubbish) within $10 \mathrm{~m}$ of the well?

This question checks the possibility of microbial contamination of well water from other localized sources of contamination. It is not a common practice in the Maldives to keep live stock, or pets due to the religious beliefs. However, breeding birds including hens were seen in several houses in the study islands. Open disposal of rubbish within the house plot near domestic dug wells was observed frequently in the Maldives islands. As discussed in the case of Q1, the distance checked in Q3 might be modified to $52.5 \mathrm{~m}$ in the context of the Maldives islands. However, at this distance $(52.5 \mathrm{~m})$ this hazard is most unlikely to represent hazard. Therefore the Q3 need not be modified in the case of the Maldives islands.

Q4: Is the drainage poor, causing stagnant water within $2 m$ of the well? AND,

Q5: Is there a faulty drainage channel? Is it broken, permitting ponding?

These questions check whether the wasted well water and other surface water, which potentially carries pathogens, could drain back into the well through preferential pathways. Even though the wells were built inside the washroom most of the time, the drainage was directed out of the wash room towards the garden, or garbage dumping area, or sometimes into the soakage pits of the latrines. The washrooms were either marbled or ce- mented. However, cracks on the floor of the washroom were witnessed. Therefore, in the context of the Maldives islands, these questions, Q4 and Q5 are valid and don't need to be modified, but become Q3 and Q4 respectively.

Q6: Is the wall (parapet) around the well inadequate, allowing surface water to enter the well?

Question 6 checks whether any contaminated surface water, can potentially enter into the well due to an inadequate, damaged parapet wall. Only in very rare occurrences was the parapet wall around the well observed to be inadequate in the Maldives study islands. However, this can be a potential hazard in the context of the Maldives and thus remains a valid question as Q5.

Q7: Is the concrete floor less than $1 \mathrm{~m}$ wide around the well?

As in the case of questions four and five, question seven checks whether any potentially contaminated surface water can enter into the well water through preferential pathways, in the absence of $1 \mathrm{~m}$ wide plinth around the well. This could be another potential observable sanitary hazard in the Maldives islands. Yet, it is a common practice observed in the Maldives islands, to build the domestic well within the wash room (next to the latrine)! Since, the wells are located within the washroom, most of the time the plinth around the well happens to be wider than $1 \mathrm{~m}$ (with floor tiles or concrete paving). Consequently, this remains a major concern and the question is retained as Q6.

Q8: Are the walls of the well inadequately sealed at any point for $3 \mathrm{~m}$ below ground?

This question checks the availability of preferential pathways for the polluted water interflow to enter into the well. Since the groundwater table in the Maldives islands is very shallow (about 2 to $3 \mathrm{~m}$ ), this question can be an important potential hazard identification question in the Maldives islands' context. It is therefore valid in the Maldives and becomes Q7.

Q9: Are there any cracks in the concrete floor around the well which could permit water to enter the well?

Once again question 9 checks the presence of preferential pathways for the polluted water to reach the well water. Even though most of the wells in the Maldives islands are located within the wash room with a wide plinth present around the well, still the floor can have cracks. Therefore question 9 is valid in the Maldives islands' context and becomes Q8.

Q10: Are the rope and bucket left in such a position that they may become contaminated?

A metal or plastic container attached to a pole, called a "Dhani", is the means of manual abstraction used in the Maldives islands to abstract groundwater. However, increasing usage of demand driven pressure pumps are also observed in the study islands for flushing the toilets and in the kitchens. When the "dhani" was used for well wa- 
ter abstraction, often it was left in an unsanitary position. Therefore, question ten is a valid question in the case of the Maldives islands and can be modified as Q9: Is the groundwater abstraction means ("Dhani") left in such a position that it may become contaminated?

Q11: Does the installation require fencing?

Question 11 checks whether any animals can reach the well head and cause contamination of the surface water (by excreting) which can then reach the well water through preferential pathways. Pet breeding is unusual in the Maldives islands except for a few cases of birds breeding. Birds cannot be restrained from reaching the well using a fence. Hence this question is not useful in the case of the Maldives islands and is removed.

Therefore, in the context of the Maldives islands, the sanitary survey form for open dug wells was modified as follows:

Q1: Is there a latrine within $52.5 \mathrm{~m}$ of the well? Is it on higher ground than the well?

Q2: Is there any other source of pollution (e.g. animal excreta, rubbish) within $10 \mathrm{~m}$ of the well?

Q3: Is the drainage poor, causing stagnant water within $2 \mathrm{~m}$ of the well?

Q4: Is there a faulty drainage channel? Is it broken, permitting ponding?

Q5: Is the wall (parapet) around the well inadequate, allowing surface water to enter the well?

Q6: Is the concrete floor less than $1 \mathrm{~m}$ wide around the well?

Q7: Are the walls of the well inadequately sealed at any point for $3 \mathrm{~m}$ below ground?

Q8: Are there any cracks in the concrete floor around the well which could permit water to enter the well?

Q9: Is the groundwater abstraction means ("Dhani") left in such a position that it may become contaminated?

The answers to the first sanitary survey question in the modified list are all "Yes" for all study wells except in Vilufushi island in the Maldives islands. Vilufushi Island was under complete reconstruction of the infrastructure and residential buildings after the complete inundation by the Year 2004 tsunami brought sea water, during the study period. Hence only 425 construction workers and officials were occupying the Vilufushi Island at that time. Hence the island had couple of on-site sanitation systems built next the residences of the workers and officials. The answers to the rest of the questions are the same as those observed using the sanitary survey form for open dug wells published by WHO [11]. Therefore the frequency of occurrence of the sanitary hazards of the modified sanitary survey form is summarized in Table 8.

\subsection{Faecal Coliform Counts vs. Sanitary Hazard Score}

To understand the strength of correlation between the FC counts and the SHS, the FC observations were plotted against the SHS for each study area. This will test the hypothesis that increasing number of hazard points are broadly correlated with increasing level of groundwater faecal contamination.

The FC count observations varied from zero/100ml to Too Numerous to Count (TNTC). In order to accommodate this wide range of FC counts, the base ten logarithmic $\mathrm{FC}$ counts $\left(\log _{10} \mathrm{FC}\right)$ are plotted against the observed SHS of each studied groundwater source in the following graphs. To avoid $\log 0$ issues 0.1 is added to each FC count. Counts as high as $30,000 \mathrm{FC} \mathrm{cfu} / 100 \mathrm{ml}$ sample are assigned to FC count observations denoted as TNTC and CG (Confluent Growth).

The correlation coefficient value of the curves (Table 9) is the square root of the $R^{2}$ value. It is a tool used to express the level of correlation between the two parameters studied. The correlation coefficient values suggest the following relationships between the parameters:

0 to 0.3 : weak correlations;

0.3 to 0.7 : moderate correlation e.g. Daravandhoo (logarithmic correlation, Graph 1);

0.7 to 1: good correlations.

Table 8. Frequency (percentage) of occurrences of the sanitary hazards listed in the modified sanitary survey form in the Maldives islands.

\begin{tabular}{|c|c|c|c|c|c|c|c|c|c|c|}
\hline \multirow{2}{*}{ Island } & \multicolumn{9}{|c|}{ Sanitary hazard points (Yes: 1, No: 0 ) } & \multirow{2}{*}{$\begin{array}{c}\text { Number } \\
\text { of well } \\
\text { surveys }\end{array}$} \\
\hline & 1 & 2 & 3 & 4 & 5 & 6 & 7 & 8 & 9 & \\
\hline Vilufushi & $1(16.7)$ & $4(66.7)$ & $6(100.0)$ & $6(100.0)$ & $4(66.7)$ & $5(83.3)$ & $4(88.7)$ & $6(100.0)$ & $1(16.7)$ & 6 \\
\hline Thimarafushi & $22(100.0)$ & $17(77.3)$ & $4(18.2)$ & $1(4.55)$ & $0(0.0)$ & $2(9.09)$ & $4(18.2)$ & $11(50.0)$ & $19(86.4)$ & 22 \\
\hline Veymandoo & $16(100.0)$ & $15(93.8)$ & $10(62.5)$ & $9(56.3)$ & $1(6.25)$ & $13(81.3)$ & $0(0)$ & $15(93.8)$ & $10(62.5)$ & 15 \\
\hline Burunee & $16(100.0)$ & $14(87.5)$ & $3(18.8)$ & $1(6.25)$ & $0(0.0)$ & $12(75.0)$ & $3(18.8)$ & $14(87.5)$ & $11(68.8)$ & 16 \\
\hline Fenfushi & $15(100.0)$ & $8(53.3)$ & $8(53.3)$ & $7(46.7)$ & $2(13.3)$ & $8(53.3)$ & $2(13.3)$ & $10(66.7)$ & $9(60.0)$ & 15 \\
\hline Thoddoo & $15(100.0)$ & $11(73.3)$ & $12(80.0)$ & $11(73.3)$ & $3(20.0)$ & $14(93.3)$ & $3(20.0)$ & $14(93.3)$ & $11(73.3)$ & 15 \\
\hline Daravandhoo & $10(100.0)$ & $7(70.0)$ & $6(60.0)$ & $7(70.0)$ & $0(0.0)$ & $6(60.0)$ & $0(0.0)$ & $7(70.0)$ & $6(60.0)$ & 10 \\
\hline Overall & $95(96.0)$ & $76(76.0)$ & $49(49.5)$ & $42(42.4)$ & $10(10.1)$ & $60(60.6)$ & $16(16.2)$ & $77(77.8)$ & $67(67.7)$ & 99 \\
\hline
\end{tabular}


Table 9. Summary of linear correlation coefficient $\left(R^{2}\right)$ values of $\log _{10} F C$ counts vs. SHS curves.

\begin{tabular}{ccccc}
\hline Study island & Study period & Linear correlation coefficient & Study period & Linear correlation coefficient \\
\hline Vilufushi & Jan-08 & 0.0204 & - & - \\
Thimarafushi & Jan-08 & 0.0928 & May-08 & 0.0604 \\
Veymandoo & Jan-08 & 0.0241 & May-08 & 0.0139 \\
Burunee & Jan-08 & 0.0902 & May-08 & 0.0379 \\
Fenfushi & Feb-08 & 0.0043 & - & - \\
Thoddoo & May-08 & 0.0378 & Dec-08 & - \\
Daravandhoo & Oct-08 & 0.3564 & & 0.4624 \\
\hline
\end{tabular}
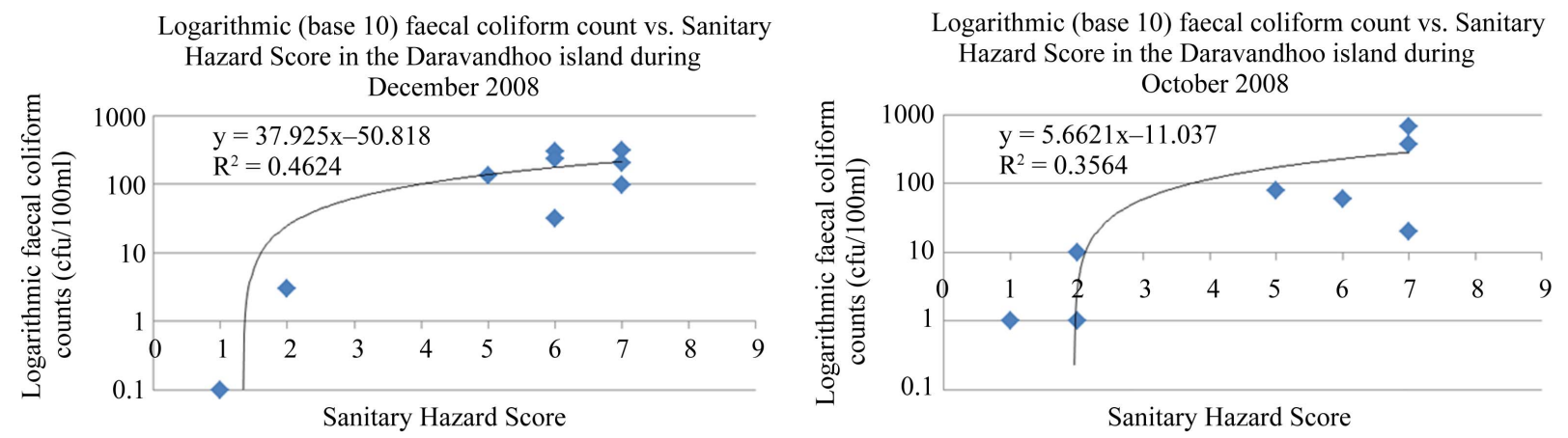

Graph 1. Plot of the $\log _{10}$ FC counts vs. Sanitary Hazard Score observed in Daravandhoo Island during October and December 2008.

The correlation coefficient values summarized in Table 9 indicates that the correlation between the observed FC counts and the SHS's are generally weak. Only Daravandhoo Island shows moderate correlations (Graph 1).

However in both of the scenarios the observed frequency of the sanitary hazards (Table 8) did not show any noticeable trend. Therefore the reasons for the differing correlations observed could be that most of the hazards present in the study islands, other than Daravandhoo island, are not significantly contributing to faecal contamination of well water compared with the proximity of well to latrine effluent. Otherwise there may be other contributory factors such as rainfall or population density influencing the FC counts and the correlations between the LogFC counts and the SHS. Therefore there is a fundamental need to assess the relative weight of each observable sanitary hazard listed in the survey form.

The population density can be an important factor in the context of the Maldives islands, because of the very small size of the study islands and the lack of safe separation distance between the open dug well and the latrine pits. However, the impact of the population density can be underwhelmed by strictly following the standards of (water sealed) septic tank construction together with a tile field for further treatment of septic tank effluent before it reaches the groundwater body. In other words by efficiently containing the contaminants at the source the impact of the population density on the microbial well water quality can be reduced.

The population density is not the major contributor for the observed higher levels of faecal contamination (above D grade) in the Maldives setting, as it shows a weak correlation (Table 10 and Graph 2) with higher levels faecal contamination.

The rainfall impact during the survey in May-08 in Veymandoo Island and during both October and December 2008 in Daravandhoo island (Table 11) were insensitive to the observed FC counts (Graph 3). That is heavy rainfall event (Table 12) showed least correlation with the observed FC counts while light rain showed no significance. Having observed least correlation between heavy rainfall event and observed faecal coliform counts implies that the impact from rainfall is not significant in the Maldives islands.

\subsection{Combined Risk Analysis}

Lloyd and Helmer [8] used the criteria in Table 13 to assess the relative risk of water supplies using the combined analysis of FC grades and the sanitary hazard score classification, and to prioritize the water supplies for remedial action. The faecal grade and the sanitary risk grades used in Table $\mathbf{1 3}$ are presented in Tables $\mathbf{3}$ and $\mathbf{1 4}$. However, Lloyd and Boonyakarnkul [10] used a slightly different sanitary inspection risk score classification scheme for tube wells (Table 14). 
Table 10. Population density in the Maldives study islands.

\begin{tabular}{ccccc}
\hline Study island & Period & $\begin{array}{c}\text { Population } \\
\text { density (/ha) }\end{array}$ & $\begin{array}{c}\text { Samples with } \\
\text { above FC grade } \\
\text { D (\%) }\end{array}$ & $\begin{array}{c}\text { No. of } \\
\text { samples }\end{array}$ \\
\hline Vilufushi & Jan-08 & 7 & 80 & 5 \\
Thimarafushi & Jan-08 & 166 & 72.7 & 22 \\
Veymandoo & Jan-08 & 25 & 61.9 & 21 \\
Burunee & Jan-08 & 85 & 62.5 & 16 \\
Fenfushi & Feb-08 & 33 & 25 & 16 \\
Thoddoo & May-08 & 9 & 50 & 16 \\
Daravandhoo & Oct-08 & 18 & 0 & 8 \\
\hline
\end{tabular}

Table 11. Daily rainfall in Veymandoo and Daravandhoo islands during two batches of surveys.

\begin{tabular}{ccccc}
\hline Island & \multicolumn{2}{c}{ Veymandoo } & \multicolumn{2}{c}{ Dharavandhoo } \\
\hline Survey type & Date & Rainfall (mm) & Day & Rainfall (mm) \\
\hline & 12-Jan-08 & 36.8 & & \\
$1^{\text {st }}$ survey & 13-Jan-08 & 0 & 17-Oct-08 & 0 \\
& 14-Jan-08 & 0 & & Trace \\
& 24-May-08 & 0 & & 16-Dec-08 \\
\hline
\end{tabular}

Source: [14].

Table 12. Classification of rainfall intensity.

\begin{tabular}{cccc}
\hline American meteorological society & UK meteorological office \\
\hline $\begin{array}{c}\text { Rainfall intensity } \\
(\mathrm{mm} / \mathrm{hr})\end{array}$ & Classification & $\begin{array}{c}\text { Rainfall intensity } \\
(\mathrm{mm} / \mathrm{hr})\end{array}$ & Classification \\
\hline Trace to 2.5 & Light rain & Less than 0.5 & Slight rain \\
2.6 to 7.6 & Moderate rainfall & 0.5 to 4 & Moderate rain \\
over 7.6 & Heavy rainfall & Greater than 4 & Heavy rain \\
\hline
\end{tabular}

Sources: $[15,16]$.

Table 13. Lloyd and Helmer's [8] combined risk analysis of sanitary inspection and faecal coliform contamination.

\begin{tabular}{cc}
\hline Faecal grade + Sanitary hazard grade & Action priority \\
\hline A + No Risk & No Action \\
B + Low Risk & Low Priority \\
C + Intermediate to high risk & $\begin{array}{c}\text { Higher Priority; As soon as } \\
\text { the resources permit }\end{array}$ \\
D/E + Very high Risk & $\begin{array}{c}\text { Highest Priority; Most } \\
\text { urgent action }\end{array}$ \\
\hline
\end{tabular}

Table 14. Sanitary inspection risk score classifications.

\begin{tabular}{cccc}
\hline \multicolumn{2}{c}{ Lloyd and Helmer (1991) } & \multicolumn{2}{c}{ Lloyd and Boonyakarnkul (1992) } \\
\hline Hazard score & Risk & Hazard score & Risk \\
\hline 0 & No risk & $0-2$ & Low risk \\
$1-3$ & Low risk & $3-5$ & Intermediate risk \\
$4-6$ & $\begin{array}{c}\text { Intermediate to } \\
\text { high risk }\end{array}$ & $6-8$ & High risk \\
& & &
\end{tabular}

$\begin{array}{cccc}7->10 & \text { Very high risk } & 9-10 \quad \text { Very high risk } \\ \text { Sources: }[8,10] . & \end{array}$

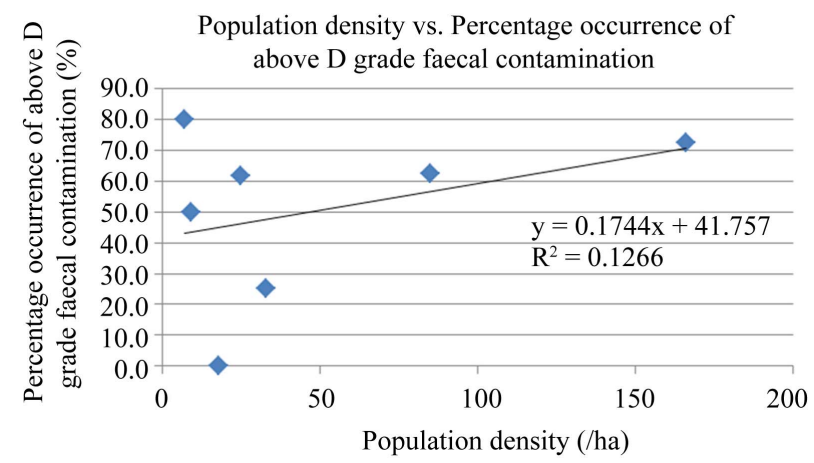

Graph 2. Plot of the population density in the study islands vs. the percentage occurrence of above-D grade faecal contamination levels.
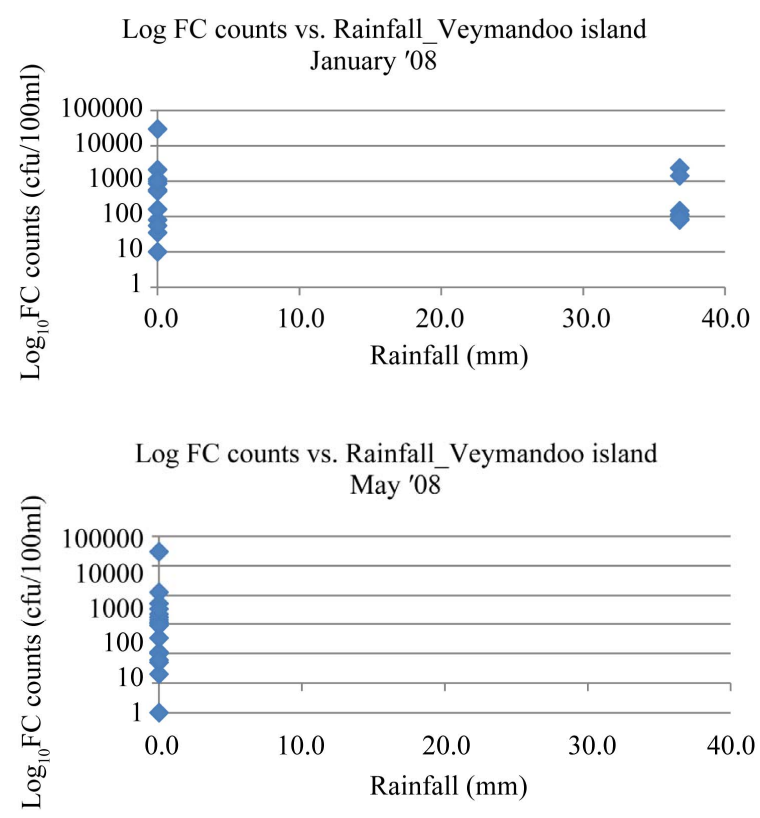

Graph 3. Plot of the rainfall intensity vs. the observed FC counts in Veymandoo island, during January and May 2008.

The sanitary inspection form used in this study for dug wells, lists all the observable sanitary hazard points that are attached to a particular groundwater point source. A zero sanitary inspection score indicates that there is no 
observable risk attached to the studied open dug well. The aim of the combined sanitary risk analysis (Table 13) is to prioritize remedial action in large collections of wells, by identifying and removing observable hazards.

However, the vulnerability (and level of contamination) of a point groundwater source is also dependent on the hydrogeology of the aquifer from which the groundwater is tapped. In shallow, highly porous or fissured aquifers such as limestone aquifers with large solution cavities, contaminated groundwater originating from remote locations, distances much greater than the required safe separation distance between a sanitation system and the groundwater point source, can easily reach the well water. In this scenario, even with a zero observable sanitary hazard score the groundwater point source could be at considerable risk. Hence, in this hydro-geological setting, the inclusion of zero sanitary hazard score within the "low risk" group is a more logical approach. Because of this the slightly modified form of the Lloyd and Boonyakarnkul's [10] sanitary hazard inspection risk classification scheme (Table 15) is used in this paper as the basis for the combined risk analysis.

Similarly, because of the observed large variation in FC counts during a few hours (Table 6), a single (or even duplicate) zero thermo-tolerant FC observation may not mean zero risk, but low risk [4]. Therefore the E. coli/FC classification in Table $\mathbf{1 6}$ is used in the combined risk analysis of sanitary conditions and FC con tamination (Table 17) in this paper.

According to Table 18, less than $7.2 \%$ of the wells in the study areas are at low risk and hence of low action priority. Unfortunately, above $57.7 \%$ of the wells in the study are at very high risk of microbial contamination and require urgent action.

The idea of combined risk analysis was used [8]

Table 15. Sanitary inspection risk score classification.

\begin{tabular}{cc}
\hline Hazard score & Risk \\
\hline $0-2$ & Low risk \\
$3-5$ & Intermediate risk \\
$6-8$ & High risk \\
$\geq 9$ & Very high risk \\
\hline
\end{tabular}

Table 16. $E$. coli/faecal coliform classification scheme for water supplies.

\begin{tabular}{ccc}
\hline Grade & $\begin{array}{c}\text { Faecal coliform } \\
\text { counts/100ml }\end{array}$ & Risk \\
\hline A & 0 & Low risk \\
B & $1-10$ & Low risk \\
C & $11-100$ & Intermediate to high risk \\
D & $101-1000$ & Gross pollution; high risk \\
E & $>1000$ & Gross pollution; very high risk \\
\hline
\end{tabular}

Table 17. Combined risk analysis of sanitary inspection and faecal coliform contamination.

\begin{tabular}{|c|c|}
\hline Faecal grade + Sanitary Hazard grade & Action priority \\
\hline $\mathrm{A} / \mathrm{B}+$ Low risk & Low Priority \\
\hline $\mathrm{C}+$ Intermediate to high risk & $\begin{array}{l}\text { Higher Priority; As soon as } \\
\text { the resources permit }\end{array}$ \\
\hline $\mathrm{D} / \mathrm{E}+$ Very high Risk & $\begin{array}{l}\text { Highest Priority; Most } \\
\text { urgent action }\end{array}$ \\
\hline
\end{tabular}

mainly to group the study wells according to the relative risk of faecal contamination and to prioritize remedial action. Since a majority of the wells in Table $\mathbf{1 8}$ are categorized as at very high risk and require urgent action, there is a need for further prioritization among the "very high risk" group of wells to cope with the limited resources. Elsewhere [10] assessing the relative significance of individual hazards helped to prioritize remedial actions, but in the Maldives all wells need protection from direct gross contamination of the aquifer by septic tank effluents.

\section{Conclusions}

The list of sanitary hazards occurring in open dug wells, which was published by Lloyd \& Helmer [8] and WHO [11], required revision under the naturally high vulnerability hydro-geological setting of the Maldives islands. A modified list of sanitary hazards was developed with justifications and applied here. It can be used in future sanitary surveys in the Maldives and similar small island scenarios.

As a preliminary approach using plots of graphs of combined risk assessments, proposed equal weighting for all the observable sanitary hazards with open dug wells was proposed [8], even though the relative weighting will vary in reality [10]. However, the combined risk assessment revealed that more than $50 \%$ of the wells studied in the Maldives islands are at high risk, requiring urgent action to reduce faecal microbial contamination. Improving all identified wells with respect to all the observed sanitary hazards would involve substantial capital costs which are not readily available in developing countries such as the Maldives islands. Consequently the observable sanitary hazards need to be weighted using a multivariate analysis [10], to prioritize and economize on rehabilitation work. Pilot remedial action projects are required to demonstrate that sanitary hazards with the highest weighting are carried out first to demonstrate significant water quality improvements.

It has been shown that faecal contamination of aquifers in the Maldives is almost ubiquitous. This is due, in large part, to the proximity of septic tanks to the wells. The generally weak correlations between the total of sanitary hazards and FC counts reflect the dominance of 
Table 18. Grouping of open dug wells according to the associated risk of faecal contamination, arranged by study areas.

\begin{tabular}{|c|c|c|c|c|c|}
\hline Survey type & Study area & No. of wells & $\begin{array}{l}\text { Low risk: Low action } \\
\text { priority (No.) }\end{array}$ & $\begin{array}{l}\text { Intermediate to high risk: Higher } \\
\text { action priority (No.) }\end{array}$ & $\begin{array}{l}\text { Very high risk: Urgent } \\
\text { action (No.) }\end{array}$ \\
\hline \multirow{9}{*}{$\begin{array}{l}1^{\text {st }} \text { batch of } \\
\text { surveys }\end{array}$} & Vilufushi & 5 & 0 & 1 & 4 \\
\hline & Thimarafushi & 21 & 0 & 5 & 16 \\
\hline & Veymandoo & 17 & 0 & 4 & 13 \\
\hline & Burunee & 16 & 0 & 6 & 10 \\
\hline & Fenfushi & 15 & 3 & 8 & 4 \\
\hline & Thoddoo & 16 & 1 & 5 & 9 \\
\hline & Daravandhoo & 8 & 3 & 5 & 0 \\
\hline & Total & 97 & 3 & 38 & 57 \\
\hline & $\%$ occurrence & & $7.20 \%$ & $35.10 \%$ & $57.70 \%$ \\
\hline \multirow{6}{*}{$\begin{array}{l}2^{\text {nd }} \text { batch of } \\
\text { surveys }\end{array}$} & Thimarafushi & 22 & 0 & 5 & 17 \\
\hline & Veymandoo & 17 & 0 & 6 & 11 \\
\hline & Burunee & 16 & 0 & 9 & 7 \\
\hline & Daravandhoo & 9 & 2 & 2 & 5 \\
\hline & Total & 64 & 2 & 22 & 40 \\
\hline & $\%$ occurrence & & $3.10 \%$ & $34.40 \%$ & $62.50 \%$ \\
\hline
\end{tabular}

one or two hazards, principally the influence of septic tanks on groundwater contamination. The potential influence of other contributory factors to the faecal contamination of well water such as rainfall (to a lesser degree) and, notably, population density, appears to be much less significant.

Considering all the facts discussed earlier (and based on the BGS ARGOSS [4]), it is explicit that maintaining a safe separation distance between an open dug well and an on-site sanitation system is not possible in most of the Maldives islands. Consequently, the top priority should be the improvement of septic tank design and performance. This will enhance the effective containment of the pollutants at the source level (in the source-pathwayreceptor relationship). Once the overwhelming influence from the septic tanks on groundwater contamination is significantly reduced/eliminated, a follow-up surveillance study will help to evaluate the efficacy of the septic tank improvement programme in improving the well water quality, and to judge the impact from the other observable sanitary hazards listed in the sanitary survey form.

\section{Acknowledgements}

This project was carried out with the practical support of the Director and staff of the Maldives Water and Sanitation Authority (MWSA), Republic of Maldives, and with the financial support of the Mayor of Karlsruhe's post- tsunami charitable fund managed by Stadtwerke Karlsruhe, Germany.

\section{REFERENCES}

[1] T. Falkland, "Report on Integrated Water Re-Sources Management and Sustainable Sanitation for Four Islands," Republic of Maldives MWSA/UNICEF, September 2001 .

[2] T. Falkland, "Draft Report on Groundwater Investigations, Northern Development Region," The Republic of Maldives Regional Development Project, First phase, ADB/ The Maldives Ministry of Planning and National Development/MacAlister Elliott and Partners Ltd/OPT International/BFS Consulting Group, August 2001.

[3] "Maldives Water and Sanitation Authority/GWP Consultants Water Resources Tsunami Impact Assessment and Sustainable Water Sector Recovery," September 2005.

[4] ARGOSS, "Guidelines for Assessing the Risk to Groundwater from On-Site Sanitation," British Geological Survey Commissioned Report, CR/01/142, 2001, 97 p.

[5] A. A. Cronin, S. Pedley, N. Breslin and R. G. Taylor, "Assessing the Risk to Groundwater Quality from Unsanitary Well Completion and On-Site Sanitation," 2nd International Symposium on Ecological Sanitation, Luebeck, April 2003, pp. 431-436.

[6] S. Godfrey, F. Timo and M. Smith, "Micro-Biological Risk Assessment and Management of Shallow Groundwater Sources in Lichinga, Mozambique," Water and En- 
vironmental Journal, Vol. 20, 2006, pp. 194-202.

[7] G. Howard, S. Pedley, M. Barret, M. Nalubega and K. Johal, "Risk Factors Contributing to Microbiological Contamination of Shallow Groundwater in Kampala, Uganda," Water Research, Vol. 37, No. 14, 2003, pp. 34213429. doi:10.1016/S0043-1354(03)00235-5

[8] B. J. Lloyd and R. Helmer, "Surveillance of Drinking Water Quality in Rural Areas Logman Scientific \& Technical," Co-published in the United States with John Wiley \& Sons, Inc., New York, 1991.

[9] S. E. Sutton, "Microbiological Quality of Groundwater Supplies in Rural Zambia Groundwater Quality," Chapman and Hall, 1994.

[10] B. J. Lloyd and T. Boonyakarnkul, "Combined Assessment of Sanitary Hazards and Faecal Coliform Intensity for Rural Groundwater Supply Improvement in Thailand," Proceedings of a National Conference on Geologic Resources of Thailand: Potential for Future Development, Department of Mineral Resources, Bangkok, 1992, pp.

\section{Abbreviations}

ARGOSS: Assessing Risk to Groundwater from On-site Sanitation;
$17-24$.

[11] WHO, "Guidelines for Drinking Water Quality," 2nd Edition, Vol. 3, Surveillance and Control of Community Supplies, 1997.

[12] T. Falkland, "Draft Report on Groundwater Investigations, Addu atoll," Southern Development Region, The Republic of Maldives ADB/The Maldives Ministry of Planning and National Development, December 2000.

[13] ISO 9308-1, "Water Quality-Detection and Enumeration of Coliform Organisms, Thermotolerant Coliform Organisms and Escherichia coli," 1990.

[14] Department of Meteorology, The Maldives Islands.

[15] American Meteorological Society, Glossary of Meteorology.

http://amsglossary.allenpress.com/glossary/search?id=rai $\mathrm{n} 1$

[16] United Kingdom Meteorological Office. http://www.metoffice.gov.uk/

MWSA: Maldives Water and Sanitation Authority;

GoM: Government of Maldives;

UNICEF: United Nations Children's fund. 